\title{
Analyzing effect of teachers' personal empowerment perceptions' to their passion for working by various factors
}

\begin{abstract}
Önder ŞANLI
Department of Knowledge Management, Besni Vocational School of Higher Education, Adıyaman Üniversity, Turkey.

Received 13 February, 2017; Accepted 20 May, 2019

The aim of this research is to determine the relationship between the elementary, middle and high school teachers' personal empowerment perception and passion for working. During the research, opinions of 890 teachers' chosen from different schools and branches with random sampling technique were collected from those working in Malatya province in the 2016-2017 academic year. As a data collection tool, "Personal Empowerment Scale" and "The Measurement of Engagement" were used. The results of the analyses revealed that the average of the Personal Empowerment scale extent ranges around "frequently". The perception level of the participants related to personal empowerment scale was in the range of "high". All the averages related to the measurement of engagement were in the range of "frequently". It was observed that participants evaluated their level related to the measurement of engagement in high ebb. When the values related to gender variable points to personal empowerment scale's "choice" extent, it suggested that average values related to the perceptions of male teachers are higher than that of the female teachers. It was seen that "effect" behaviors of teachers predicts "vigor" meaningfully. Further, that "content" behaviors of teachers predicts "absorption" meaningfully.
\end{abstract}

Key words: Personal empowerment, passion for working, teachers.

\section{INTRODUCTION}

Usually, personal empowerment is used in acknowledgement of "empowerment". Empowerment is defined as knowledge information and sharing with low levels (Hales and Klidas, 1998), re-distribution of the decision making power in a way that it will involve those who does not have this power (Cunningham et al., 1996), offering opportunities of deciding on their job to working personnel or providing an environment that can make them take responsibility of their own operations (Erstad, 1997). Empowerment emphasizes that it depends on individuals' perception and reflects the cognitive states of low levels about empowerment (Thomas and Velthouse,

E-mail:ondersanli44@hotmail.com.

Author(s) agree that this article remain permanently open access under the terms of the Creative Commons Attribution License 4.0 International License 
1990). In this context, power and control concepts are promoted with power indicated as a necessity (Conger and Kanungo, 1988). This necessity is brought to the fore when people feel that they possess the power or when they believe that they can cope with cases, conditions, options and humans. The power however is found in four different manners in an organisation as personality power, speciality power, fund power and position power (Conger and Kanungo, 1988).

Personal Empowerment involves all those four types of power. The job's being meaningful is associated with value of the mission or purpose for the individual, stating his perception effects satisfaction level and empowerment emotion that will be obtained from the job. An individual feeling of himself/herself as adequate for the job is defined as one where the job is accomplished with just enough effort. An individual having the opportunity of choosing his job is related to an individual that controls his/her job as he/she pleases, making operations about job on his/her own and controlling work environment. Also, feeling efficient at work implies that the perception of individual's behaviors can make a difference (Sigler and Pearson, 2000). Basic principles in an empowerment model can be listed as below (Darling, 1996; Genç, 2004).

(i) A leadership system should be established before everything.

(ii) A strong dual communication should be established and supported.

(iii) Application groups should be generated.

(iv) An awarding system about the performance management of organisation should be established.

(v) Support of the reliable personnel is needed.

(vi) A supporting service related to leadership team among the personnel relationships should be established.

(vii) Measurement and performance framework which involves only the necessary information should be established.

Russ (1995) listed the factors necessary for a personnel empowerment system;

(i) Acceptance of personal empowerment is not a technique, but a philosophy.

(ii) The necessity of being clear and accurate while making evaluation.

(iii) Understanding, knowledge and skills are important.

(iv) Expectations should be realistic and should not be imaginative.

(v) Failure is an opportunity for learning.

(vi) Personal empowerment process requires time.

Personal empowerment means, personnel having their own work, being proud of what they do and being free about what they do in exchange for sharing the risks and responsibilities. For the success of personal empowerment which involves opportunities and risks, manager and personnel should be in touch with each other in accordance with organisation's goals and should make this a part of the organisation (Randolph, 2000).

In cases where personnels are not empowered and the culture of empowerment is not common (Carroll, 1994):

(i) Individuals focus on spending free time and are concerned with their own work.

(ii) Problems and mistakes are hidden or not taken seriously.

(iii) Focusing on policies takes time and resources cannot be assigned in order to solve the problems of customers and shareholders.

(iv) Decisions are made mostly based on the ideas of senior managers.

(vi) Goals and measurements are not argued and determined.

(vii) Communication is weak.

(viii) Collisions are not solved and might cause destructive reasons for the organisation.

(ix) Feedback is avoided.

(x) Personnel avoid taking risks, afraid of making mistakes.

(xi) Personnel are neutral to the problems of the organisation.

(xii) Poor performance is not cared about.

(xiii) Traditional management system is depended upon.

(xiv) Laziness and disappointments are the basic problems faced in the organisation.

However, in his study, Carroll (1994) also expressed regarding organizations in which personal empowerment is common:

(i) Individuals and teams take action in accordance with the goals of the organisation.

(ii) Underlying reasons of problems and mistakes can be clearly argued.

(iii) For solving the problems, trouble among the organisation and clients are focused upon.

(iv) The decisions are made in accordance with accurate information shared in the organisation.

(v) Goals and measurements are clearly determined.

(vi) Cross-communication and emotion of cooperation between the personnel is created.

(vii) Collisions are shared clearly and solutions are searched in the cooperation of managers and personnel.

(viii) Feedback is given regularly among the organisation.

(ix) Risk is perceived as an opportunity for growing and developing, whereas learning from mistakes made in organisation is common.

(x) Reasons for poor performance are investigated and solutions are recommended.

(xi) Contrary to traditional system, innovativeness is at 
the forefront, with personnels encouraged to be innovative.

\section{Passion for working}

This is defined as "positive, satisfying, cognitive state about work" (Schaufeli et al., 2002) that involves three extents; vigor, dedication, and absorption. Vigor extent involves high energy level, cognitive strength, a will to make an effort and not getting tired easily while working. An individual who is enormously vigorous while working is motivated about work and even though he/she is faced with difficulties, continues to work with a steadiness. Dedication represents a strong commitment to work and involves the feeling of importance, eagerness, inspiration, honour and struggle. The individuals who are dedicated to work think that their job is interesting, requires struggle, serves a meaningful purpose; and the job they do inspires them, so they do it eagerly and be proud of it. Absorption refers to an individual's totally focusing on work, hooked on to work, does not understand how the time goes by and hard;y gives himself a break.

These job features may also include the role of extrinsic motivation because these are tools for individual to reach his/her goals (Meijman and Mulder, 1998). These work spaces that hosts those resources encourages an individual to dedicate his/her skills to work. Therefore, individual's successful completion of their work and the chance of reaching their goal is high. Put differently, opportunity to use autonomy and several skills raise an individuals' chance of being successful. In this regard, it can be thought as a facilitative feature for individuals who want to demonstrate their job features. For example, individuals who can manage jobs that require different skills experience the feeling of demonstrating their skills to others in an unchallenged way and might approach this sort of a working activity more passionately.

The concept of passion for working is used (Ardıç and Polatçı, 2009) in different studies as ensorcelling to work (Bal, 2008), abandon to work (Öner, 2008), and passion (Turgut, 2011). The passion for working is also accepted as opposite of exhaustion. The ones who are passionate for work and also act in contrast to exhaustion are individuals who are energetic, who think they can meet with the responsibilities and requirements of their work easily and love their job. However, it is not possible to say that individuals who do not experience the burnout syndrome are passionate for work. For this reason, passion for work and exhaustion should be considered separately from each other (Schaufeli and Bakker, 2008). Passion for working is a cognitive state characterized by vigor, dedication and absorption to work. Rather than a temporary cognitive state, passion for work does not change in a short period of time. Vigor extent of passion for work is expressed with being strong and energetic cognitively while working. Eagerness of an individual to work is the topic under consideration. Dedication to work is however expressed with an individual taking work seriously, be attached to it, holding on to it with enthusiasm and be proud of it. In absorption extent, the individual who focuses on his/her job enjoys while working and fulfills his/her duties happily. An individual focuses on work not because of the extrinsic factors but because of loving it and does not realize how time flies. The individual also tries to overcome the problems which he/she focus upon at work (Schaufeli and Bakker, 2008).

\section{Purpose of the study}

This study is geared towards determining the relationship between elementary, middle and high school teachers' personal empowerment perception and passion for working. The relationship between teachers' perception about personal empowerment and passion for work and age, gender, seniority, branch, working period at same school, school type variables as well as the relationship between personal empowerment and passion for working extent are examined based on the questions below:

1) What is the level of teachers' perception according to personal empowerment extent and passion for working extent?

2) Are the teachers' perception according to personal empowerment notably different due to marital status, gender, school type, branch, service years in job, work years at school and age?

3) Is there a meaningful relationship between personal empowerment extent and passion for working according to teachers' perception?

4) Does it show a meaningful difference in relation to predicting of age, seniority, gender and marital status while still predicting teachers' effect perception to vigor.

5) Does it show a meaningful difference related to predicting of age, seniority, gender and marital status while still predicting teachers' understanding perception to absorption?

\section{METHODOLOGY}

\section{Research group}

The research group consists of 890 teachers who were working in public schools in Malatya province in the 2016-2017 academic year and chosen from schools and branches with random sampling technique. Elementary schools, middle schools, and high schools are counted in the research. Other defining information related to the teachers' research group that participated in the research is summed up in Table 1. 
Table 1. Demographic information related to reseach group about teachers' who participated in the research.

\begin{tabular}{|c|c|c|c|}
\hline Variable & Category & $\mathbf{N}$ & $\%$ \\
\hline \multirow{3}{*}{ Gender } & Male & 516 & 58 \\
\hline & Female & 374 & 42 \\
\hline & Total & 890 & 100.0 \\
\hline \multirow{3}{*}{ Marital status } & Married & 724 & 81.3 \\
\hline & Single & 166 & 18.7 \\
\hline & Total & 890 & 100.0 \\
\hline \multirow{6}{*}{ Age } & Between $20-30$ years & 168 & 18.9 \\
\hline & Between 31-40 years & 373 & 41.9 \\
\hline & Between $41-50$ years & 268 & 30.1 \\
\hline & Between $51-60$ years & 77 & 8.7 \\
\hline & $61-61+$ years & 4 & .4 \\
\hline & Total & 890 & 100.0 \\
\hline \multirow{5}{*}{ Service years in job } & Between 1-10 years & 312 & 35.1 \\
\hline & Between $11-20$ years & 363 & 40.8 \\
\hline & Between 21-30 years & 179 & 20.1 \\
\hline & Between31-31+ years & 36 & 4.0 \\
\hline & Total & 890 & 100.0 \\
\hline \multirow{6}{*}{$\begin{array}{l}\text { Working period at } \\
\text { the same school }\end{array}$} & Between 1-5 years & 602 & 67.6 \\
\hline & Between $6-10$ years & 174 & 19.6 \\
\hline & Between $11-15$ years & 68 & 7.6 \\
\hline & Between 16-2 years & 26 & 2.9 \\
\hline & Between 21-21+ years & 20 & 2.2 \\
\hline & Total & 890 & 100.0 \\
\hline \multirow{3}{*}{ Branch } & Form Teacher & 207 & 23.3 \\
\hline & Other Branches & 683 & 76.7 \\
\hline & Total & 890 & 100.0 \\
\hline \multirow{4}{*}{ School type } & Elementary School & 235 & 26.4 \\
\hline & Middle School & 238 & 26.7 \\
\hline & High School & 417 & 46.9 \\
\hline & Total & 890 & 100.0 \\
\hline
\end{tabular}

\section{Data collection tools}

This is developed by the researchers to determine the specific demographic characteristics of the teacher who participates in this research. In this form, questions about age, gender, service years, marital status, working period at the same school and school type was included.

\section{Personal empowerment scale}

This was developed by Spreitzer, (1995) and adapted into Turkish by Gümüşlüoğlu and Karakitapoğlu-Aygün (2009). The scale is separated into four sections, viz; meaning, self sufficiency, choice and effect and consists of 12 questions. The statements are evaluated with five-point Likert Scale which is scaled from 1 "Strongly Disagree" to 5 "Strognly Agree". The reliability rate of the questions on passion for working, which is present in the scale's question form, is calculated as 0.895 Cronbach Alpha. This rate is on a grade that may be counted as reliable statistically.

\section{The measurement of engagement}

This was developed by Schaufeli et al. (2002) and adapted into Turkish by Turgut (2011). The scale consists of 17 questions in 
Table 2. Likert evaluation criterion of the survey matters.

\begin{tabular}{llll}
\hline Value & Options & Gap & Level \\
\hline $\mathbf{1}$ & Never & $1.00-1.80$ & Quite Low \\
$\mathbf{2}$ & Seldom & $1.81-2.60$ & Low \\
$\mathbf{3}$ & Sometimes & $2.61-3.40$ & Average \\
$\mathbf{4}$ & Frequently & $3.41-4.20$ & High \\
$\mathbf{5}$ & Always & $4.21-5.00$ & Quite High \\
\hline
\end{tabular}

Table 3. Associated correlation level between the scales.

\begin{tabular}{ll}
\hline $\mathbf{r}$ & Relationship level \\
\hline $0.00-0.25$ & Quite Weak \\
$0.26-049$ & Weak \\
$0.50-0.69$ & Avarage \\
$0.70-0.89$ & High \\
$0.90-1.00$ & Quite High \\
\hline
\end{tabular}

Table 4. Values related to the extents of personal empowerment scale.

\begin{tabular}{lccc}
\hline Variable & $\mathbf{X}$ & $\begin{array}{c}\text { Standard } \\
\text { error }\end{array}$ & $\begin{array}{c}\text { Standard } \\
\text { deviation }\end{array}$ \\
\hline Meaning & 4.1549 & 0.02330 & 0.69511 \\
Self Sufficiency & 4.0123 & 0.02339 & 0.69765 \\
Choice & 3.8257 & 0.02416 & 0.72073 \\
Effect & 3.9713 & 0.02303 & 0.68709 \\
Personal Empowerment (General) & 3.9910 & 0.02057 & 0.61366 \\
\hline
\end{tabular}

Table 5. Values related to the extents of passion for working scale.

\begin{tabular}{lccc}
\hline Variable & $\mathbf{X}$ & $\begin{array}{c}\text { Standard } \\
\text { error }\end{array}$ & $\begin{array}{c}\text { Standard } \\
\text { deviation }\end{array}$ \\
\hline Vigour & 3.9082 & 0.02444 & 0.72920 \\
Commitment & 4.1173 & 0.02629 & 0.78436 \\
Absorption & 3.7487 & 0.02561 & 0.76403 \\
Passion For Working (General) & 3.9134 & 0.02279 & 0.67981 \\
\hline
\end{tabular}

total; six of which are vigor extent, 5 of them passion extent and 6 of them absorption extent. The reliability rate of the questions on passion for working which is present in the scale's question form is calculated as 0.89 Cronbach Alpha. This rate is on a grade that may be counted as reliable statistically. Likert evaluation criterion related to the survey matters about the "Personal Empowerment Scale" and "Measurement of Engagement Scale" is shown in Table 2.

The choices' gaps evaluated according to determined participation rate by group $(4 / 5=0.80)$ is acquired by dividing the five-point scale's $(5-1=4)$ differentials to the value judgement $(5)$ in the questionnaire. The values related to Perceived Stress Scale extents in Table 4 and those related to Burnout Scale in Table 5 are interpreted according to the values shown in Table 2. Pearson's coefficient of correlation is used in researching the relationship between factors. The associated correlation of the scales is evaluated according to the criterions below (Kalaycı, 2006). Correlation relation levels between the scales can be seen in Table 3 . $95 \%$ of the acquired findings are evaluated in security level while $5 \%$ of them are evaluated in meaningfulness level. Wrong entry fixing, wrong codification, gapfilling and extreme value cleaning of the acquired data has been done before going into analysis.

\section{Data collection procedure and analysis}

In statistical analysis of the data, SSPS 22.0 package program for descriptive analysis, $\mathrm{T}$ test for independent variables, one-way 
Table 6. t-Test values belonging to Extent of Personal Empowerment Scale's "Choice Variable" related to the gender groups.

\begin{tabular}{lcccccc}
\hline Gender & $\mathbf{N}$ & $\overline{\mathbf{x}}$ & Standard Deviation & $\mathbf{s d}$ & $\mathbf{t}$ & $\mathbf{p}$ \\
\hline Male & 516 & 3.8824 & 0.72140 & 888 & 2.766 & $0.006^{* *}$ \\
Female & 374 & 3.7475 & 0.71340 & & & \\
Total & 890 & & & & & \\
\hline
\end{tabular}

${ }^{*} p<0.05^{* *} p<0.01{ }^{* * *} p<0.001$

Table 7. Values belonging to extent of personal empowerment scale's "choice variable" related to the school type groups.

\begin{tabular}{lccc}
\hline School type & $\mathbf{N}$ & $\overline{\boldsymbol{X}}$ & Standard deviation \\
\hline Elementary School & 235 & 3.9220 & 0.73461 \\
Middle School & 238 & 3.7497 & 0.71027 \\
High School & 417 & 3.8148 & 0.71446 \\
Total & $\mathbf{8 9 0}$ & $\mathbf{3 . 8 2 5 7}$ & $\mathbf{0 . 7 2 0 7 3}$ \\
\hline
\end{tabular}

Table 8. Personal Empowerment Scale's Extent Of 'Choice' one way ANOVA results according to groups of school types.

\begin{tabular}{llcccccc}
\hline Source of the variance & $\begin{array}{c}\text { Sum of the } \\
\text { squares }\end{array}$ & sd & $\begin{array}{c}\text { Mean of the } \\
\text { squares }\end{array}$ & $\mathbf{F}$ & $\mathbf{p}$ & Meaningful difference \\
\hline \multirow{4}{*}{ Choice } & Inter-group & 3.60 & 2 & 1.803 & 3.49 & $0.031^{*}$ & $\begin{array}{l}\text { (Between and middle school) } \\
\text { andary }\end{array}$ \\
& In-group & 458.18 & 887 & 0.517 & & & \\
& Total & 461.79 & 889 & & & & \\
\hline
\end{tabular}

${ }^{*} p<0.05^{* *} p<0.01{ }^{* * *} p<0.001$.

analysis of variance (ANOVA), Pearson's product-moment correlation coefficient and multilinear regression analysis are used.

\section{FINDINGS}

Here, for solving research's problem, findings which are acquired as a result of the analysis of data collected from teacher via scales are included. Explanations and comments based on the findings are delivered. When Table 4 is examined, it is observed that averages related to personal empowerment scale are in the gap of 3.414.20 (Frequently). Based on that, it can be said that perception level related to participants' personal empowerment is "high". Also, from Table 4, it is seen that averages related to passion for working scale are in the gap of 3.41- 4.20 (Frequently). According to that, it can be said that participants highly evaluated the passion for working.

However, a meaningful differentiation was observed between 'personal empowerment' extent and marital status $(p=0.06>0.05)$, working period for same school $(p=0.095>0.05)$ and age $(p=0.311>0.05)$ variables is not found. Also, a meaningful relationship was observed between "choice" extent and gender $(p=0.006<0.05)$, school type $(p=0.03<0.05)$, and branch $(p=0.04<0.05)$, between the variables "self-sufficiency" extent and branch $(p=0.03<0.05)$, service years in job, "choice" and "meaning" extent with service years in job as well as personal empowerment scale's "general" and branch and service years in job. The findings belonging to this relationship is given in Tables 6, 7, 8, 9, 10 and 11. When groups perceived rate "choice" extent points of the personal empowerment scale is examined, the values related to gender; average values of the male teachers were found to be higher than the female teachers. In addition, the questions in the "choice variable" extent, is about personnel deciding their operations at work on their own.

As in Table 8, there is a significant difference in personal empowerment scale's extent of choice points' one-way ANOVA according to variant of choice and 
Table 9. $t$ Test values belonging to branch variable points related to personal empowerment scale, self sufficiency and general of personal empowerment scale

\begin{tabular}{|c|c|c|c|c|c|c|c|}
\hline Branch & & $\mathbf{N}$ & $\overline{\bar{x}}$ & Standart deviation & sd & $t$ & $p$ \\
\hline \multirow{3}{*}{ Choice } & Form & 207 & 3.9149 & 0.73735 & & & \\
\hline & Other & 683 & 3.7987 & 0.71397 & 888 & 2.036 & $0.042^{*}$ \\
\hline & Total & 890 & & & & & \\
\hline \multirow{3}{*}{ Self-Sufficiency } & Form & 207 & 4.1043 & 0.69306 & & & \\
\hline & Other & 683 & 3.9844 & 0.69713 & 888 & 2.172 & $0.030^{*}$ \\
\hline & Total & 890 & & & & & \\
\hline \multirow{3}{*}{$\begin{array}{l}\text { Persoanal empowerment } \\
\text { (General) }\end{array}$} & Form & 207 & 4.0659 & 0.62618 & & & \\
\hline & Other & 683 & 3.9684 & 0.60846 & 888 & 2.006 & $0.045^{*}$ \\
\hline & Total & 890 & & & & & \\
\hline
\end{tabular}

${ }^{*} p<0.05{ }^{* *} p<0.01{ }^{* * *} p<0.001$.

Table 10. Values belonging to Extent of Personal Empowerment Scale's "Self-Sufficiency", "Effect", "Meaning", "General of Personal Empowerment" Related to the Service Years In Job.

\begin{tabular}{lccc}
\hline Self Sufficiency & $\mathbf{N}$ & $\overline{\mathbf{x}}$ & Standard deviation \\
\hline Between 1- 10 years & 312 & 3.9793 & 0.69556 \\
Between 11- 20 years & 363 & 3.9606 & 0.72446 \\
Between 21- 30 years & 179 & 4.1881 & 0.60583 \\
Between 31- 31+ years & 36 & 3.9444 & 0.75383 \\
Total & 890 & 4.0123 & 0.69765 \\
Effect & $\mathbf{N}$ & $\overline{\mathbf{x}}$ & Standard deviation \\
Between 1- 10 years & 312 & 3.9091 & 0.70567 \\
Between 11- 20 years & 363 & 3.9468 & 0.70657 \\
Between 21- 30 years & 179 & 4.1194 & 0.61342 \\
Between 31- 31+ years & 36 & 4.0196 & 0.57784 \\
Total & 890 & 3.9713 & 0.68709 \\
Meaning & $\mathbf{N}$ & $\overline{\mathbf{x}}$ & Standard deviation \\
Between 1- 10 years & 312 & 4.1286 & 0.69696 \\
Between 11- 20 years & 363 & 4.1005 & 0.73773 \\
Between 21- 30 years & 179 & 4.3103 & 0.57499 \\
Between 31- 31+ years & 36 & 4.1594 & 0.69683 \\
Total & 890 & 3.8257 & 0.72073 \\
Personal empowerment (General) & $\mathbf{N}$ & $\overline{\mathbf{x}}$ & Standard deviation \\
Between 1- 10 years & 312 & 3.9550 & 0.60364 \\
Between 11- 20 years & 363 & 3.9486 & 0.66000 \\
Between 21- 30 years & 179 & 4.1356 & 0.51804 \\
Between 31- 31+ years & 36 & 4.0120 & 0.56534 \\
Total & 890 & 3.9910 & 0.61366 \\
\hline
\end{tabular}

analysis of Post-Hoc Schheffe between the elementary school and middle school $(F(2-989)=3.490, p<0.05)$.
When we look at the table of the groups' average values, the $t$ belonging to teachers' "choice" perception is 
Tablo 11. Personal Empowerment Scale's Extent Of 'Self-Sufficiency, Effect, Meaning, and General of Personal Empowerment' Points' One Way ANOVA results according to groups of Service Years In The Job.

\begin{tabular}{|c|c|c|c|c|c|c|c|}
\hline \multicolumn{2}{|c|}{ Source of the variance } & \multirow{2}{*}{$\begin{array}{c}\text { Sum of the } \\
\text { squares }\end{array}$} & \multirow{2}{*}{$\begin{array}{c}\text { sd } \\
3 \\
886\end{array}$} & \multirow{2}{*}{$\begin{array}{c}\begin{array}{c}\text { Mean of the } \\
\text { squares }\end{array} \\
2.336 \\
0.480\end{array}$} & \multirow{2}{*}{$\frac{\mathbf{F}}{4.863}$} & \multirow{2}{*}{$\frac{\mathbf{p}}{0.002^{\star \star}}$} & \multirow{2}{*}{$\begin{array}{l}\text { Meaningful difference } \\
\text { (Between the years range } \\
\text { of } 1-10 \text { and } 21-30 \text { ) }\end{array}$} \\
\hline \multirow{2}{*}{ Self-Sufficiency } & $\begin{array}{l}\text { Inter Groups } \\
\text { In - Group }\end{array}$ & & & & & & \\
\hline & Total & 432.684 & 889 & & & & $\begin{array}{l}\text { (Between the years range } \\
\text { of } 11-20 \text { and } 21-30 \text { ) }\end{array}$ \\
\hline Effect & $\begin{array}{l}\text { Inter Groups } \\
\text { In - Group } \\
\text { Total }\end{array}$ & $\begin{array}{c}5.434 \\
414.260 \\
419.694\end{array}$ & $\begin{array}{c}3 \\
886 \\
889\end{array}$ & $\begin{array}{l}1.811 \\
0.468\end{array}$ & 3.874 & $0.009^{* *}$ & $\begin{array}{l}\text { (Between the years range } \\
\text { of } 1-10 \text { and } 21-30 \text { ) }\end{array}$ \\
\hline \multirow{2}{*}{ Meaning } & $\begin{array}{l}\text { Inter Groups } \\
\text { In - Group }\end{array}$ & $\begin{array}{c}5.613 \\
423.929\end{array}$ & $\begin{array}{c}3 \\
886\end{array}$ & $\begin{array}{l}1.871 \\
0.478\end{array}$ & 3.910 & $0.009^{\star *}$ & $\begin{array}{l}\text { (Between the years range } \\
\text { of } 1-10 \text { and } 21-30 \text { ) }\end{array}$ \\
\hline & Total & 429.542 & 889 & & & & $\begin{array}{l}\text { (Between the years range } \\
\text { of } 11-20 \text { and } 21-30 \text { ) }\end{array}$ \\
\hline \multirow{2}{*}{$\begin{array}{l}\text { Persoanal } \\
\text { Empowerment } \\
\text { (General) }\end{array}$} & $\begin{array}{l}\text { Inter Groups } \\
\text { In - Group }\end{array}$ & $\begin{array}{c}4.814 \\
329.962\end{array}$ & $\begin{array}{c}3 \\
886\end{array}$ & $\begin{array}{l}1.605 \\
0.372\end{array}$ & 4.309 & $0.005^{\star \star}$ & $\begin{array}{l}\text { (Between the years range } \\
\text { of } 1-10 \text { and } 21-30 \text { ) }\end{array}$ \\
\hline & Total & 334.776 & 889 & & & & $\begin{array}{l}\text { (Between the years range } \\
\text { of } 11-20 \text { and } 21-30 \text { ) }\end{array}$ \\
\hline
\end{tabular}

${ }^{*} p<0.05^{* *} p<0.01{ }^{* * *} p<0.001$

significantly high. A meaningful relationship between elementary school teachers (X̄elementary school=3.922) and middle school teachers ( $\overline{\mathrm{X}}_{\text {middle }}$ school $\left.=3.749\right)$ is found to be remarkable indicating that perception of "choice" belonging to elementary school teachers are higher.

The values belonging to Branch Variable Points Related to Personal Empowerment Scale, Self Sufficiency and general Personal Empowerment Scale in Table 9 suggests that in all three extents, average values belonging to their perceptions are higher than the other branch teachers. There is a significant difference in personal empowerment scale's extent of 'self sufficiency points' one-way ANOVA according to variant of seniority in job and analysis of Post-Hoc Schheffe between the group whose service years in the job are from 1 to 10 years and the group whose service years in the job are from 21 to 30 years $(F(3-889)=4.863, p<0.01)$. With reference to the table of the groups' average values, it can be seen that "self-sufficiency" perception of teachers' points are significantly higher. It has been found that there is a significant relationship between teachers that have $1-10(\overline{\mathrm{X}} 1-10$ year=3. 9793) service years in the job and teachers that have 21-30 ( $\mathrm{x} 21-30$ year=4.1881) service years in the job. It has been determined that the teachers that have 21-30 service years in the job have a higher perception of 'self-sufficiency'. Moreover, a significant relationship has been found between teachers that have $11-20(\overline{\mathrm{X}} 11-20$ year=3.9606) service years in the job and teachers that have $21-30\left(\overline{\mathrm{X}}_{2} 1-30\right.$ year $=$ 4.1881) service years in the job; it has also been found that teachers that have 21-30 service years in the job have a higher perception of 'self sufficiency'. As for 'effect' extent, it has been determined that there is a significant relationship between teachers that have 1-10 $(\overline{\mathrm{X}} 1-10$ year=3.909) service years in the job and teachers that have $21-30(\overline{\mathrm{X}} 21-30 \mathrm{yl}=4.1194)$ service years in the job $(F(3-889)=3.874, p<0.01)$. As regards 'concept' extent, it has been determined that there is a significant relationship between teachers that have 1-10 ( $\overline{\mathrm{X}}_{1-10}$ year $=4.128)$ service years in the job and teachers that have 21-30 $(\overline{\mathrm{x}} 21-30$ year $=4,310)$ service years in the job $(F(3-889)=3,910, p<0,01)$. It is seen that teachers that have 21-30 service years in the job have a higher level of perception of 'overall' personal empowerment scale. It is also seen that teachers that have 21-30 service years in the job have a higher perception of 'concept'. Moreover, it has been found that there is a significant relationship in extent of 'concept' between teachers that have 11-20 $\left(\overline{\mathrm{X}}_{11-20}\right.$ year $\left.=4.100\right)$ service years in the job and teachers that have $21-30(\bar{x} 21-30$ year $=4.310)$ service years in the job. Further, it is noteworthy that perceptions 
Table 12. Table of correlation that belongs to extents of personal empowerment and passion for working scale.

\begin{tabular}{|c|c|c|c|c|c|c|c|c|c|}
\hline Variable & $\begin{array}{c}\text { Pe. } \\
\text { Meaning }\end{array}$ & $\begin{array}{c}\text { Pe. Self } \\
\text { Sufficiency }\end{array}$ & $\begin{array}{c}\text { Pe. } \\
\text { Choice }\end{array}$ & $\begin{array}{c}\text { Pe. } \\
\text { Effect }\end{array}$ & $\begin{array}{c}\text { Pe. } \\
\text { General }\end{array}$ & $\begin{array}{c}\text { PfW. } \\
\text { Vigour }\end{array}$ & $\begin{array}{c}\text { PfW. } \\
\text { Commitment }\end{array}$ & $\begin{array}{c}\text { PfW. } \\
\text { Absorption }\end{array}$ & $\begin{array}{c}\text { PfW. } \\
\text { General }\end{array}$ \\
\hline Pe. Meaning & 1 & & & & & & & & \\
\hline Pe.Self Sufficieny & $0.747^{\text {t*t* }}$ & 1 & & & & & & & \\
\hline Pe. Choice & $0.584^{* * *}$ & $0.702^{* * *}$ & 1 & & & & & & \\
\hline Pe. Effect & $0.642^{* * *}$ & $0.760^{\star * *}$ & $0.713^{* * *}$ & 1 & & & & & \\
\hline Pe. General & $0.847^{* * *}$ & $0.915^{* * *}$ & $0.858^{* * *}$ & $0.887^{* * *}$ & 1 & & & & \\
\hline PfW. Vigour & $0.536^{* * *}$ & $0.556^{* * *}$ & $0.475^{\star \star \star}$ & $0.516^{* * *}$ & $0.594^{* * *}$ & 1 & & & \\
\hline PfW. Commitment & $0.552^{* * *}$ & $0.588^{* * *}$ & $0.455^{* * *}$ & $0.549^{* * *}$ & $0.611^{* * *}$ & $0.772^{* * *}$ & 1 & & \\
\hline PfW. Absorption & $0.481^{* \star *}$ & $0.521^{* * *}$ & $0.466^{* * *}$ & $0.485^{\star * *}$ & $0.557^{* * *}$ & $0.674^{* * *}$ & $0.681^{* * *}$ & 1 & \\
\hline PfW. General & $0.581^{* * *}$ & $0.617^{* * *}$ & $0.519^{* * *}$ & $0.574^{* * *}$ & $0.653^{* * *}$ & $0.908^{* * *}$ & $0.902^{* * *}$ & $0.883^{* * *}$ & 1 \\
\hline
\end{tabular}

${ }^{*} p<0.05^{* *} p<0.01{ }^{* * *} p<0.001$

of 'concept' of the teachers that have $21-30$ service years in the job are higher.

When the values that belong to 'overall' personal empowerment scale is examined, it has been determined that there is a significant relationship between views of the teachers that have $1-10\left(\overline{\mathrm{X}}_{1}-10 \mathrm{yll}=3.955\right)$ service years in the job and views of teachers that have 21$30(\overline{\mathrm{X}} 21-30 \mathrm{yll}=4.135)$ service years in the job $(F(3-889)=$ $4.309, p<0,01)$. It is seen that teachers that have spent $21-30$ service years in the job have a higher level of perception of 'overall' personal empowerment scale. Moreover, significant relationship has been found in 'overall' personal empowerment scale dimensions; also, that the level of perception of 'overall' personal empowerment scale of the teachers that have 21-30 service years are higher.

Due to correlation analysis indicated in Table 12, a positive relationship was observed between 'concept' extent of 'personal empowerment scale' and all of the extents of personal empowerment scale along with passion for working scale. Because the relationship between 'concept' and 'self-sufficiency' extent is ( $r=0.747$; $r^{2}=0.580$ ), $58 \%$ of behaviour of 'concept' is explained with behaviour of 'self-sufficiency'; because the relationship between 'concept' and 'effect' is ( $\left.r=-0.584 ; r^{2}=0.341\right)$, $34,1 \%$ of behaviour of 'concept' is explained with behaviour of meaning; because the relationship between 'concept' and 'effect' is ( $\left.r=-0.642 ; r^{2}=0.412\right), 41.2 \%$ of behaviour of 'concept' is explained with 'effect'; because the relationship between 'concept' and 'overall' personal empowerment scale is $\left(r=-0.847 ; r^{2}=0.717\right), 71.7 \%$ of behaviour of 'concept' is explained with 'overall' personal empowerment scale; because the relationship between 'concept' and 'strength' extent of passion for working scale is $\left(r=-0.536 ; r^{2}=0.287\right), 28.7 \%$ of behaviour of 'concept' is explained with behaviour of 'strength'; and because the relationship between 'concept' and 'commitment' is ( $\left.r=-0.552 ; r^{2}=0.304\right), 30.4 \%$ of behaviour of 'concept' is explained with behaviour of 'commitment'. Further, because the relationship between 'concept' and 'absorption' is ( $\left.r=0.481 ; r^{2}=0.231\right), 23.1 \%$ of behaviour of 'concept' is explained with behaviour of 'absorption'; and because the relationship between 'concept' and 'overall' passion for working scale is $\left(r=0.581 ; r^{2}=0.337\right), 33,7 \%$ of behaviour of 'concept' is explained with behaviour of 'overall' passion for working scale.

A positive relationship was found between 'selfsufficiency' extent of personal empowerment scale extents and the extents of personal empowerment scale and passion for working scale. It was seen that there is a high relationship between 'self-sufficiency' extent and 'selection' extent, an ultrahigh relationship between 'selection' extent and 'overall' personal empowerment scale, and a medium level relationship among all extents of passion for working scale. There is a 'high' relationship between 'concept', 'self-sufficiency' and 'overall' personal empowerment scale, a low ebb of relationship between 'concept' extent and 'effect' extent, and a medium level relationship between 'concept' extent and the rest of the extent of 'selection', 'effect', 'strength', 'commitment' and 'overall' passion for working'. Because the relationship between 'self-sufficiency' extent and 'selection' extent is $\left(r=0.702 ; \quad r^{2}=0.492\right), \quad 49.2 \%$ of behaviour of 'selfsufficiency' is explained with the behavior of 'selection'; because the relationship between 'self-sufficiency' and 'effect' is $\left(r=-0.760 ; r^{2}=0.577\right), 57.7 \%$ of behaviour of 'self-sufficiency' is explained with behaviour of 'effect'; because the relationship between 'self-sufficiency' extent and 'overall' personal empowerment, $83,7 \%$ of behaviour of 'self-sufficiency' is explained with 'overall' personal empowerment scale. Because the relationship between 'self-sufficiency' and 'strength' extent of passion for working scale is $\left(r=-0.915 ; r^{2}=0.837\right), 30.9 \%$ of behaviour of 'self-sufficiency' is explained with behaviour of 'strength'; because the relationship between 'selfsufficiency' and 'commitment' is $\left(r=-0.556 ; r^{2}=0.309\right)$, $34.5 \%$ of behaviour of 'self-sufficiency' is explained with 
behaviour of 'commitment'; because the relationship between 'self-sufficiency' and 'absorption' is ( $r=-0.588$; $r^{2}=0.345$ ), $27.1 \%$ of behaviour of 'self-sufficiency' is explained with behaviour of 'absorption'; and because the relationship ( $\left.r=0.617 ; r^{2}=0.380\right)$ between 'self-sufficiency' and 'overall' passion for working scale is $(r=0.521$; $\left.r^{2}=0.271\right), 38 \%$ of behaviour of 'self'sufficiency' is explained with 'overall' behaviour of passion of working scale. It has been found that there is a positive relationship between 'selection' extent of personal empowerment scale extents and all of the extents of passion for working scale. It is seen that there is a high level relationship between 'selection' extent, 'effect' extent and overall personal empowerment scale; however, it is seen that there is a medium level relationship between 'selection' extent and all of the extents of passion for working. It can be said that because the relationship between 'selection' extent and 'effect' is $\left(r=-0.713 ; r^{2}=0.508\right), 50.8 \%$ of behaviour of 'selection' is explained with behaviour of 'effect'; because the relationship between 'selection' extent and overall personal empowerment scale is $\left(r=-0.858 ; r^{2}=0.736\right)$, $73.6 \%$ of behaviour of 'selection' is explained with 'overall' personal empowerment scale; because the relationship between 'selecion' and 'strength' extent is $\left(r=0.475 ; r^{2}=0.225\right), 22.5 \%$ of behavior of 'selection' is explained with behaviour of 'strength'; because the relationship between 'selection' and 'commitment' is ( $r=-$ $0.455 ; r^{2}=0.207$ ), $20.7 \%$ of behaviour of 'selection' is explained with behaviour of 'commitment'; because the relationship between 'selection' and 'absorption' is $\left(r=0.466 ; r^{2}=0.217\right), 21.7 \%$ of behaviour of 'selection' is explained with behaviour of 'absorption'; and because of the fact that relationship between 'selection' and 'overall' passion for working scale is $\left(r=0.519 ; r^{2}=0.269\right), 26.9 \%$ of behaviour of 'selection' is explained with 'overall' behaviour of passion for working scale.

It has been found that there is a positive relationship between 'effect' extent and personal empowerment scale extents as well as the extents of personal empowerment scale and passion for working scale. It is seen that there is a high level relationship between 'effect' extent and 'overall' personal empowerment scale; however, it is seen that there is a medium level relationship between 'effect' extent and 'overall' supporting standard scale. It is seen that because the relationship between 'effect' extent and 'overall' personal empowerment scale is $(r=-0.887$; $\left.r^{2}=0.786\right), 78.6 \%$ of behavior of 'effect' is explained with 'overall' personal empowerment scale; because the relationship between 'effect' and 'strength' extent of passion for working scale is $\left(r=0.516 ; r^{2}=0.266\right), 26.6 \%$ of behaviour of 'effect' is explained with behavior of 'strength'; because the relationship between 'effect' and 'commitment' is $\left(r=-0.549 ; r^{2}=0.301\right), 30.1 \%$ of behaviour of 'effect' is explained with behaviour of 'commitment'; because the relationship between 'effect' and 'absorption' is $\left(r=0.485 ; r^{2}=0.235\right), 23.5 \%$ of behaviour of 'effect' is explained with behavior of 'concentreation'; and because the relationship between 'effect' and 'overall' passsion for working scale is $\left(r=0.574 ; r^{2}=0.329\right), 32.9 \%$ of behaviour of 'effect' is 'overall' behaviour of passion for working.

It has been found that there is a positive relationship between 'overall' supporting of staff scale and all of the extents of passion for working scale. It is seen that there is a medium level relationship between 'overall' personal empowerment scale and all of the extents of passion for working scale. Because the relation between 'overall' personal empowerment scale and extent of 'strength' of passion for working scale is $\left(r=0.594 ; r^{2}=0.352\right), 35.2 \%$ of 'overall' behaviour of passion for working scale is explained with behaviour of 'strength', because that the relationship between 'overall' personal empowerment scale and 'commitment' is ( $\left.r=-0.611 ; r^{2}=0.373\right), 37,3 \%$ of 'overall' behaviour of personal empowerment scale is explained with behaviour of 'commitment'; because the relationship between 'overall' personal empowerment scale and 'absorption' is $\left(r=0.557 ; r^{2}=0.310\right), 31 \%$ of 'overall' behaviour of personal empowerment scale is explained with behaviour of 'absorption'; and because the relationship between 'overall' personal empowerment scale and 'overall' passion for working scale is $(r=0.653$; $r^{2}=0.426$ ), $42.6 \%$ of 'overall' of personal empowerment scale is explained with 'overall' behaviour of passion for working scale.

It has been found that there is a postive relationship between 'strength' extent of passion for working scale and all of the extents. There is a high level relationship between 'strength' and 'commitment', a medium level relationship between 'strength' and 'commitment', an ultrahigh relationship between 'strength' and 'overall' passion for working scale. Because the relationship between 'strength' and 'commitment' is ( $r=-0.772$; $\left.r^{2}=0.595\right), 59,5 \%$ of behaviour of 'strength' is explained with behaviour of 'commitment'; because the relationship between 'strength' and 'absorption' is $\left(r=0,674 ; r^{2}=0.454\right)$, $45.4 \%$ of behaviour of 'strength' is explained with behaviour of 'absorption' and because the relationship between 'strength' and 'overall' passion for working scale is $\left(r=0.908 ; r^{2}=0.824\right), 82.4 \%$ of behaviour of 'strength' is explained with 'overall' behaviour of passion for working scale.

It has been found that there is a positive relationship between 'commitment' of passion for working scale extents and all of the extents. It is seen that there is a medium level relationship between 'commitment' and 'absorption', and an ultrahigh relationship between 'commitment' and 'overall' passion for working scale. Because the relationship between 'commitment' and 'absorption' is ( $\left.r=0.681 ; r^{2}=0.463\right), 46.3 \%$ of behaviour of 'commitmenr' is explained with behaviour of 'absorption'; and because the relationship between 'commitment' and 'overall' passion for working scale is $\left(r=0.902 ; r^{2}=0.813\right)$, 
Table 13. The results of of multilinear regression analysis of teachers' levels of 'effect'predict the 'strength'according to variables of gender, age, service years in the job and marital status.

\begin{tabular}{lllcccc}
\hline Model & & $\mathbf{B}$ & Standard Error & $\boldsymbol{\beta}$ & $\mathbf{t}$ & $\mathbf{p}$ \\
\hline \multirow{5}{*}{$1^{\text {st }}$ Step } & Stable & 3.431 & 0.239 & & 14.332 & 0.000 \\
& Gender (Dummy) & -0.059 & 0.051 & -0.040 & -1.159 & 0.247 \\
& Age & 0.008 & 0.008 & 0.095 & 1.032 & 0.302 \\
& Service Years & 0.007 & 0.008 & 0.078 & 0.854 & 0.393 \\
& Martial Status & 0.075 & 0.068 & 0.040 & 1.112 & 0.266 \\
& Stable & 1.219 & 0.241 & & & \\
& Gender (Dummy) & -0.037 & 0.044 & -0.025 & -0.843 & 0.000 \\
$2^{\text {nd }}$ Step & Age & 0.012 & 0.007 & 0.140 & 1.765 & 0.078 \\
& Service Years & -0.001 & 0.007 & -0.009 & -0.116 & 0.908 \\
& Martial Status & 0.098 & 0.058 & 0.052 & 1.676 & 0.094 \\
& P.E. Effect & $\mathbf{0 . 5 3 8}$ & $\mathbf{0 . 0 3 0}$ & $\mathbf{0 . 5 0 7}$ & $\mathbf{1 7 . 6 8 2}$ & $\mathbf{0 . 0 0 0}$ \\
\hline
\end{tabular}

Dependent Variable: Vigour $\Delta R^{2}=0.254^{* \star *}\left({ }^{*} p<0.05^{* *} p<0.01{ }^{* \star *} p<0.001\right)$.

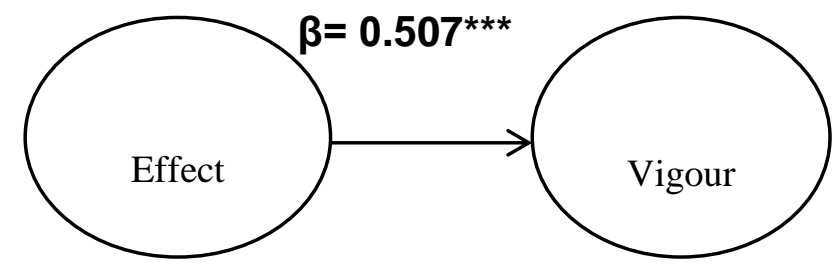

Figure 1. Effect of teachers' level of 'effect' on their level of 'strength'.

$\left({ }^{*} p<0.05^{* *} p<0.01^{* * *} p<0.001\right)$.

$81.3 \%$ of behaviour of 'commitment' is explained with 'overall' passion for working scale.

It has been found that there is a positive relationship between 'absorption' extent of passion for working scale extents and 'overall' passion for working scale. There is a high level relationship between 'absorption' and 'overall' passion for working scale. Because the relationship between 'absorption' and 'overall' passion for working scale is $\left(r=0.883 ; r^{2}=0.779\right), 77.9 \%$ of behaviour of 'absorption' is explained with 'overall' behaviour of passion for working scale.

The multilinear regression analysis has been carried out in order to find an answer to the question: 'do the teachers' perception of 'effect' show any significant difference concerning the variants of age, service years in the job, gender and marital status?' As observed in Table 13, to determine the relationship between teachers' behaviour of 'effect' and level of 'strength', variants such as gender, age, years in the job and marital status are put under control at the first step. Thereafter, it is understood from the second step that teachers' behavior of 'effect' predicts process of organizational structure in a significant way $(\beta=0.507 ; p<0.001)$ (Figure 1).
The multilinear regression analysis has been carried out to find an answer to the question: does the teachers' perception of 'effect' show any significant difference concerning the variants of age, service years in the job, gender and marital status?' As observed in Table 14, to determine the relationship between teachers' behaviour of 'concept'and level of 'absorption', variants such as gender, age, years in the job and marital status are placed under control at the first step. Thereafter, it is understood from the second step that teachers' behavior of 'concept' predicts process of organizational structure in a significant way $(\Delta R 2=0.254 ; p<0.001)$. Rise of one unit behaviour of 'effect' causes rise of 0,507 units organizational structure of level of 'strength'. When we look at the explained variant, it is seen that $25.4 \%$ of 'strength' occur with behaviour of 'effect'.

\section{Dependent variable}

The multilinear regression analysis has been conducted to answer the question: do the teachers' perception of 'concept' show any significant difference concerning the 
Table 14. The results of multilinear regression analysis of teachers' levels of 'concept' predict the 'absorption' according to variants such as gender, age, service years in the job and marital status.

\begin{tabular}{llccccc}
\hline Model & & $\mathbf{B}$ & Standard Error & $\boldsymbol{\beta}$ & $\mathbf{t}$ & $\mathbf{p}$ \\
\hline \multirow{5}{*}{$1^{\text {st }}$ Step } & Stable & 3.230 & 0.251 & & 12.869 & 0.000 \\
& Gender (Dummy) & 0.090 & 0.053 & 0.058 & 1.688 & 0.092 \\
& Age & 0.010 & 0.008 & 0.107 & 1.163 & 0.245 \\
& Service years & 0.006 & 0.008 & 0.071 & 0.783 & 0.434 \\
& Martial status & 0.013 & 0.071 & 0.007 & 0.188 & 0.851 \\
& & & & & \\
& Stable & 1.089 & 0.258 & & 4.227 & 0.000 \\
& Gender (Dummy) & 0.080 & 0.047 & 0.052 & 1.716 & 0.086 \\
$2^{\text {nd }}$ Step & Age & 0.009 & 0.007 & 0.107 & 1.314 & 0.189 \\
& Service years & 0.004 & 0.007 & 0.041 & 0.506 & 0.613 \\
& Martial status & 0.043 & 0.063 & 0.022 & 0.682 & 0.495 \\
& P.E. Meaning & $\mathbf{0 . 5 1 8}$ & $\mathbf{0 . 0 3 2}$ & $\mathbf{0 . 4 7 1}$ & $\mathbf{1 6 . 1 1 6}$ & $\mathbf{0 . 0 0 0}$ \\
\hline
\end{tabular}

Absorption $\Delta R^{2}=0.221^{* * *}\left({ }^{*} p<0.05^{* *} p<0.01{ }^{* * *} p<0.001\right)$.

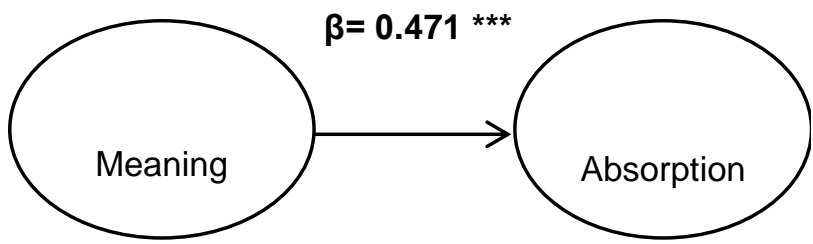

Figure 2. Effect of teachers' level of 'concept' on their level of 'absorption.

$\left({ }^{*} p<0.05{ }^{* *} p<0.01{ }^{* * *} p<0.001\right)$.

variants of age, service years in the job, gender and marital status while predicting 'absorption?'. As observed in Table 14, to determine the relationship between teachers' behaviour of 'concept' and level of 'absorption' variants such as gender, age, years in the job and marital status are get under control at the first step. Thereafter, it is understood from the second step that teachers' behavior of 'concept' predicts process of organizational structure in a significant way $(\beta=0.471 ; p<0.001)$ (Figure 2 ). Rise of one unit behaviour of 'concept' causes rise of 0,471 units organizational structure of level of 'absorption'. When we look at the explained variant, it is seen that $22.1 \%$ of 'absorption' occur with behaviour of 'concept' $(\Delta \mathrm{R} 2=0.221 ; \mathrm{p}<0.001)$.

\section{DISCUSSION}

A successful empowerment will increase efficiency of workers and bring about development for themselves by specifying authority and responsibility of lower level workers that are responsible for work results. It can also reduce decision making time; therefore, it is possible to adapt quicker to environmental conditions (Genç, 2005). It is seen that, average of extents that belong to personal empowerment scale exists in the gap of 'Mostly'. According to this, it suggests that participators have had a 'high' level perception about their levels of personal empowerment extent. It is also seen that on average, all of the extents that belong to passion for working exist in the gap of 'Mostly'. According to this, it can be said that participators have had high level evaluation about their levels of their passion for working. When 'selection' extents of personal empowerment scale's points' values that are related to the groups of gender are looked through, average belonging to male teachers' perceptions are higher than female ones'. When the selection extent questions are closely examined, it can be seen that they are related to workers' being able to decide about activities in the workplace on their own. This situation demonstrates that male teachers have much more control on activities that take place at schools than female teachers, they decide mostly on their own about how they do their job and feel much more independent 
about doing their job.

It is understood from the conducted analysis of oneway ANOVA and Post-Hoc Schheffe that there is a significant difference between the primary and secondary school. When we look at the table of the groups' average values, it is suggested that the points that belong to teachers' perception of 'selection' are significantly high. It is found that interestingly, primary school teachers' perceptions of 'selection' are higher.

This situation demonstrates that primary school teachers have much more control on activities that take place at schools than secondary school teachers, they decide mostly on their own about how they do their job and they feel much more independent about doing their job. When 'selection', 'self-sufficiency' and 'overall' personal empowerment scale extents' points to values that belong to variant of branch, it is seen that average values that belong to perceptions of primary school teachers are higher than the other branch teachers in all specified three extents. This situation demonstrates that primary school teachers care much about their jobs, have much more effect on their job, have much more selfconfidence about the job they do, feel much more independent about the work they will do and feel generally stronger at their schools than the other branch teachers. Research carried out by Demirbilek and Türkan (2008) have determined that making the workers work in a motivated way in workplace, supplying them job satisfaction, having a voice as regards deciding something about themselves or workplace, feeling safe themselves, as well as increasing the level of loyalty for their work and workplace can be real thanks to personal empowerment and that result is similar to our research's result.

According to seniority groups', points of 'self sufficiency' extent of personal empowerment scale as well as conducted analysis of one-way ANOVA and PostHoc Schheffe, it is seen that there is a significant difference between 1-10 years and 21-30 years. When we look at the table of the groups' average values, the points that belong to teachers' perception of 'self sufficiency' are significantly high. It is believed that perceptions of 'self sufficiency' of teachers that have 2130 years seniority are higher than teachers that have 110 years seniority. Moreover, it is found that there is a significant relationship between teachers that have 11-20 years seniority and teachers that have 21-30 years seniority. It is found interesting that perceptions of 'self sufficiency' of teachers that have 21-30 years seniority are higher. Barutçu and Serinkan (2008) determined that workers that have 20 years or more in the job are adequate workers for their working area and these results support our research. As for extent of 'effect', it is determined that there is a significant relation between teachers that have 1-10 years seniority and teachers that have 21-30 years seniority. It is found that levels of 'effect' of teachers that have 21-30 years seniority are higher. As for extent of 'concept', it is determined that there is a significant relation between teachers that have 1-10 years seniority and teachers that have 21-30 years seniority. It is found that levels of 'concept' of teachers that have 21-30 years seniority are higher.

Moreover, as for 'concept' extent, it is found that there is a significant relationship between teachers that have 11-20 years seniority and teachers that have 21-30 years seniority. It is found interesting that perceptions of 'concept' of teachers that have 21-30 years seniority are higher. Hançer and George (2003) determined that satisfaction, performance, loyalty and presentation of service are related to extents of concept, competence and effect and these results support our research. When the values that belong to 'overall' personal empowerment scale are examined, it is determined that there is a signfiicant relationship between teachers that have 1-10 years seniority and teachers that have 21-30 years seniority. The level of 'overall' personal empowerment scale perceptions of teachers that have 21-30 years seniority is higher. Moreover, in 'overall personal empowerment scale, it is found that there is a significant relationship between teachers that have 11-20 years seniority and teachers that have 21-30 years seniority. It is found interesting that perceptions of 'overall' personal empowerment scale of teachers that have 21-30 years seniority are higher. When all these data is examined, it is found interesting that teachers that have 21-30 years seniority have higher values than other branch teachers in all extents. The fact that teachers generally feel themselves the strongest in these years is one of the important results that can be said by looking at the findings. In the study of Ceylan et al. (2008), it is determined that the staff who has 20 or more years seniority have a higher level of job satisfaction and scores of personal empowerment and these results are also supporting the results of this research. As a result of our conducted correlation analysis, it is found that there is a positive relationship between 'concept' extent of personal empowerment scale and all of the extents of personal empowerment scale along with passion for working scale. According to findings, the most effect on extent of 'concept' is from 'overall' personal empowerment scale and the second most effect is from extent of 'self sufficiency; and this situation is found interesting.

'Self sufficiency' should not be misunderstood. Humans are social beings and we do not live in separated "bubbles" preventing us from making relationships with others (Aydoğan and Akbarov, 2018b). It is found that there is a positive relationship between 'self sufficiency' extent of personal empowerment scale extents and all of the extents of personal empowerment scale and passion for working scale. According to findings, the most effect on extent of 'self sufficiency' is from 'overall' personal 
empowerment scale and the second most effect is from extent of 'effect'. 'Self sufficiency' also should not be accepted as a subjective measure. It is found that there is a positive relationship between 'selection' extent of personal empowerment scale extents and all of the extents of personal empowerment scale as well as passion for working scale.

According to the findings, the most effect on extent of 'selection' is from 'overall' personal empowerment scale and the second most effect is from extent of 'effect'. It is found that there is a positive relationship between 'effect' extent of personal empowerment scale extents and the extents of personal empowerment scale and passion for working scale.

According to findings, it is seen that the most effect on extent of 'effect' is from 'overall' personal empowerment scale and the second most effect is from 'overall' behaviour of passion for working scale. It is found that there is a positive relationship between 'overall' personal empowerment scale and the extents of passion for working scale. When findings are examined, it is seen that the most effect on 'overall' extent of personal empowerment scale is from 'overall' passion for working scale and the second most effect is from behaviour of 'commitment' extent of passion for working scale. Both of these interesting findings are important for the aspect of showing that passion for working and personal empowerment have lots of effects on each other.

Teachers are those who are responsible for their students and lead their own group of students. Apart from teaching, they solve problems in classrooms, manage the relationship among students, and try to make learning environment rich and stimulating for students and themselves (Aydoğan and Akbarov, 2018a). It is found that there is a positive and ultra high relationship between 'strength' extent of passion for working scale extents and all of the extents. When the findings are analysed, it is seen that the most effect on 'strength' extent is from 'overall' passion for working scale and the second most effect is from behaviour of 'commitment' extent of passion for working scale. It is found that there is a positive and ultra high relationship between 'strength' extent of passion for working scale extents and all of the extents. When the findings are looked through, it is seen that the most effect on 'strength' extent is from 'overall' passion for working scale. It is found that there is a positive and ultrahigh relationship between 'absorption' extent of passion for working scale extents and 'overall' passion for working scale. It is found that there is an ultrahigh relationship between 'absorption' and 'overall' passion for working scale. It is seen that teachers' behaviour of 'effect' predicts process of organizational structure in a significant way. Rise of one-unit behavior of 'effect' causes rise of level of 'strength' of 0,507 units of organizational structure. When we look at the explained variant, it is seen that $25,4 \%$ of 'strength' ocur with behaviour of 'effect'. It is seen that teachers' behaviour of 'concept' predicts process of organizational structure in a significant way. Rise of one-unit behavior of 'effect' causes rise of level of 'absorption' of 0,471 units of organizational structure. When we look at the explained variant, it is seen that $22,1 \%$ of 'absorption' ocur with behaviour of 'concept'.

Spreitzer (1996) indicates that there are less role uncertainty among the empowered employees. Ugboro and Obeng (2000) also found meaningful relationships between the empowered employees and job satisfaction. In the study of Menon (1995), Erdil and Keskin (2003), and Pekdemir et al. (2006), a positive relationship was found between the personal empowerment and job satisfaction along with organizational commitment. Similarly, in the study of Lashley (1996), it is indicated that there is a positive relationship among the empowered employees which finds solutions to the claims of customers. It is also indicated that empowered employees are better at finding solutions to the problems of the customers. In the study of Enz (1999), it is also indicated that there is a positive relationship between speed of satisfying the needs of customers and personal empowerment.

\section{CONFLICT OF INTERESTS}

The author has not declared any conflict of interests.

\section{REFERENCES}

Ardıç, K, Polatçı S (2009). Tükenmişlik Sendromu Ve Madalyonun Öbür Yüzü: İşle Bütünleşme. Erciyes Üniversitesi İktisadi ve İdari Bilimler Fakültesi 32:21-46.

Aydoğan H, Akbarov A (2018a). Managerial Skills of English Language Teachers in Classrooms at Tertiary Level. A Turkish Pedegogical Case Study, Journal of Foreign Language Teaching and Applied Linguistics 5(2):37-48.

Aydoğan H, Akbarov A (2018b). The Relation Relationship of Some Sociodemographics and Self-Reported English Knowledge/Skills with Social Self-Esteem, Iğdr Üniv Sos Bil Der/lgdir University Journal of Social Sciences, No. 14(01-21):1-21. Igdir, Turkey.

Bal EA (2008). Self-Efficacy, Contextual Factors and Well-Being: The Impact of Work Engagement, Yayınlanmamış Doktora Tezi, Marmara Üniversitesi, Sosyal Bilimler Enstitüsü, İstanbul.

Barutçu E, Serinkan C (2008). "Günümüzün Önemli Sorunlarından Biri Olarak Tükenmişlik Sendromu ve Denizli'de Yapılan Bir Araştırma", Ege Akademik Bakış 8(2):441-461.

Carroll A (1994). "What's Behind "E" Word: Myths About Empowerment and Why You Need It", Interaction Design pp. 1-18.

Ceylan AK, Mat ÇG, Emhan E (2008). Personel Güçlendirmesi ve Yönetici Desteğinin İş Memnuniyeti Üzerindeki Etkisi: Enerji Sektöründe Bir Uygulama, İşletme Araştırmaları Dergisi 7/1:168-185.

Conger JA, Kanungo RN (1988). The Empowerment Process: Integrating Theory and Practice. Academy of Management Review 13(3):471-482.

Cunningham I, Hyman J, Baldrig C (1996). Empowerment: The Power to do What? Industrial Relation Relationships Journal 27(2):143-154.

Darling M (1996). Empowerment: Myth or Reality, Vital Speeches of the Day 62(15):474-479.

Demirbilek S, Türkan ÖU (2008). Çalışma Yaşamı Kalitesinin 
Artırılmasında Personel Güçlendirmenin Rolü, İ̧̧, Güç, Endüstri İlişkileri ve İnsan Kaynakları Dergisi Cilt:10 Sayı:1, Ocak 2008, ISSN: 13032860.

Enz A (1999). Predicting psychological empowerment among service workers: the effect of support-based relationrelationships, Human Relation Relationships 52(2):205-224.

Erdil O, Keskin H (2003). Güçlendirmeyle iş tatmini, iş stresi ve örgütsel bağılıı arasındaki ilişkiler: Bir alan çalışması, İstanbul Üniversitesi İşletme Fakültesi Dergisi, 32(1):28-35.

Erstad M (1997). Empowerment and Organizational Change. International Journal of Contemporary Hospitality Management 9(7):325-333.

Genç N (2004). Yönetim ve Organizasyon: Çağdaş Sistemler ve Yaklaşımlar, Seçkin Yayınevi, Ankara.

Genç N (2005). Yönetim ve Organizasyon (Çağdaş Sistemler ve Yaklaşımlar), 2. Baskı, Seçkin Yayıncılık, Ankara.

Gümüşlüoğlu L, Karakitapoğlu-Aygün Z (2009). Bilgi İşçilerinin Örgüte, Lidere Ve İşe Bağlılıklarını Etkileyen Faktörler, 17. Ulusal Yönetimve Organizasyon Kongresi, 21-23 Mayıs, Osmangazi Üniversitesi, Eskişehir.

Hales C, Klidas A (1998 Empowerment in five-stars hotels: Choice, voice or rhetoric?.International Journal of Contemporary Hospitality Management 10(3): 88-95.

Hançer M, George RT (2003). Psychological empowerment of nonsupervisory employees working in full-service restaurants. Hospitallity Management 22:3-16.

Kalaycı Ş (2006). Faktör analizi. spss uygulamalı çok değişkenli istatistik teknikleri. Şeref Kalaycı (Ed.). Ankara: Asil Yayın Dağıtım.

Lashley C (1996). Research issues for employee empowerment in hospitality organizations, International Journal of Hospitality Management 15(4):333-346.

Meijman TF, Mulder G (1998). "Psychological Aspects of Workload", in P.J.D. Drenth, H. Thierry (Ed.), Handbook of Work and Organizational Psychology: Work Psychology, Psychology Press, Hove 2:5-33.

Menon ST (1995). Employee Empowerment: Defination, Measurment and Construct Validation. Canada: Mc Gill University. http://digitool.library.mcgill.ca/R/?func=dbin-jumpfull\&object_id=29088\&local_base=GEN01-MCG02

Öner ZH (2008). The Mediating Effect of Organizational Justice: Moderating Roles of Sende of Coherence and Job Complexity On the Relation Relationship Between Servant Leadership and Work Engagement, Yayınlanmamış Doktora Tezi, Marmara Üniversitesi, Sosyal Bilimler Enstitüsü, İstanbul.

Pekdemir I, Özçelik O, Karabulut E, Arslantaş CC (2006). Personel güçlendirme iş tatmini ve örgütsel bağlılık arasındaki ilişkileri belirlemeye yönelik bir çalışma, Verimlilik Dergisi 4:11-36.

Randolph WA (2000). "Re-thinking Empowerment: Why Is It So Hard to Achieve?", Organizational Dynamics 29:2.

Russ DE (1995). Empowerment: A Matter of Degree-Executive Commentary, Academy of Management Executive 9(3):29-30.

Schaufeli WB, Salanova M, González-Romá V, Bakker, AB (2002). "The Measurement of Engagement and Burnout: A Two Sample Confirmatory Factor Analytic Approach", Journal of Happiness Studies 3:71-92.

Schaufeli WBT, Bakker AB (2008). Ittakestwoto tango: Workaholism is working excessively and working compulsively. In: R. J. Burke\& C. L. Cooper (Eds.), The long work hour sculture. Causes, consequences and choices (ss. 203-226). Bingley, UK: Emerald.
Sigler TH, Pearson CM (2000). Creating an Empowering Culture: Examining the RelationRelationship between Organizational Culture and Perceptions ofEmpowerment. Journal of Quality Management $5(1): 27-52$.

Sprettzer GM (1996), "Social Structural Characteristics of Psychological Empowerment", Academy of Management Journal 39(2):483-504.

Spreitzer GM (1995). Psychology empowerment in the workplace: dimensions, measurement and validation, Academy of Management Journal 38(5):1442-1465.

Thomas KW, Velthouse BA (1990). Cognitive Elements of Empowerment: An 'Interpretive' Model of Intrinsic Task Motivation. Management Review 15(4):666:681.

Turgut T (2011). Çalışmaya Tutkunluk: İş Yükü, Esnek Çalışma Saatleri, Yönetici Desteği Ve İş-Aile Çatışması İle İlişkileri. Atatürk Üniversitesi İktisadi Ve İdari Bilimler Dergisi, Cilt 25(3-4):155-179.

Ugboro IO, Obeng K (2000). "Top Management Leadership, Employee Empowerment, Job Satisfaction and Customer Satisfaction in TQM Organizations: An EmpricalStudy", Journal of Quality Management 5:247-272. 